\title{
A REVOLTA NO EGITO
}

\author{
ENTREVISTA COM HAZEM KANDIL* \\ TRADUÇÃo DE AlEXANDRE Morales
}

\section{RESUMO}

Esta entrevista enfoca a derrubada do regime autoritário egípcio em 11 de fevereiro de 2011, quando o presidente Hosni Mubarak renunciou ao posto após três décadas no poder: as razões que levaram à revolta popular, os segmentos sociais que compuseram o movimento e a forma como se deu sua mobilização, as forças que constituíam a estrutura de poder do regime deposto, o cenário sociopolítico do Egito no período de transição subsequente e as perspectivas de democratização do país.

PALAVRAS-CHaVe: Egito atual; Hosni Mubarak; Primavera Árabe; revolta popular.

\section{ABSTRACT}

This interview focuses on the fall of Hosni Mubarak's authoritarian regime in Egypt: the reasons leading to the popular uprising, the social strata that engaged in it and its mobilization strategies, the forces that supported Mubarak's regime and perspectives for the future of democracy in Egypt.

KEYWORDS: Republic of Egypt; Hosni Mubarak; Arab Spring; popular revolt.

[*] Publicada originalmente na New Left Review, n. 68, maio-abr. 2011, pp. 17-55. A entrevista foi realizada em 04/04/11.

\section{O MOVIMENTO}

Após um reinado de trinta anos, Mubarak foi deposto por um movimento popular em menos de três semanas. Como se iniciou olevante?

Ao longo dos últimos anos, uma rebelião estava fermentando sob a superfície. Havia uma sensação geral de que o status quo era insustentável. Filmes, romances e canções eram permeados pelo tema da revolta: ele estava disseminado no imaginário da população. Dois processos foram determinantes para fazer com que egípcios apolíticos, convencionais, sentissem que já não podiam seguir tocando suas vidas normais. 
O primeiro foi a dissolução do contrato social que regulava as relações entre Estado e sociedade desde o golpe de Nasser nos anos 1950. O contrato implicava um acordo tácito: o regime oferecia ensino gratuito, emprego num setor público em expansão, assistência médica a preços acessíveis, habitação barata e outras formas de proteção social em troca de obediência. Podia-se ter acesso - ou ao menos aspirar - a esses benefícios desde que as diretrizes internas e externas não fossem questionadas e o poder político não fosse contestado. Em outras palavras, a população sabia que estava trocando seus direitos políticos por bem-estar social. A partir dos anos 1980 esse contrato foi se desgastando, e no novo milênio se desfez por completo. Nesse momento, o regime acreditava que havia eliminado a resistência organizada de modo tão cabal que já não precisava pagar as tradicionais propinas sociais para garantir aquiescência política. Vendo uma população que parecia extremamente passiva, fragmentada e desanimada, o regime achou que era hora de fazer uma roubalheira de grandes proporções. No partido do governo, o Partido Democrático Nacional (PDN), uma facção agrupada em torno de Gamal Mubarak, filho do presidente, cada vez mais tomou as rédeas por meio de um novo órgão denominado Comitê de Diretrizes. Integravam-no dois segmentos. Um deles era composto de capitalistas corruptos, nutridos pelo Estado, que detinham controle monopólico sobre setores lucrativos da economia. O outro era constituído por intelectuais neoliberais, particularmente economistas que tinham vínculos com instituições financeiras internacionais.

Em 2004, o ministério de empresários do primeiro-ministro Ahmed Nazif assinalou pela primeira vez que aquele grupo efetivamente se apossara do governo. Capitalistas monopólicos assumiram pastas de grande interesse para seus ramos de atividade. Mohamed Mansour, um dos maiores revendedores de automóveis do Egito, tornou-se ministro dos Transportes. Um magnata da indústria turística, Zoheir Garraneh, tornou-se ministro do Turismo. Os intelectuais neoliberais não ficaram menos proeminentes. $O$ ministro dos Investimentos, Mahmoud Mohieddin, acabou por se tornar diretor administrativo do Banco Mundial em 2010. O ministro da Economia, Youssef Boutros-Ghali, era economista sênior do FMI e permaneceu ligado à instituição, por exemplo, ao presidir o Comitê Monetário e Financeiro Internacional, o principal órgão consultivo do Conselho Diretor do FMI para planejamento de políticas.

O resultado foi uma combinação de vergonhosa espoliação por parte dos capitalistas privilegiados e de extorsivas imposições neoliberais à população. O processo orçamentário foi reorganizado, serviços públicos foram privatizados, adotou-se um novo regime fiscal. Em 2005, as taxas tributárias sobre rendimentos de pessoas jurídi- 
cas foram cortadas pela metade, de $40 \%$ para $20 \%$, e mesmo isso raramente era pago, enquanto os impostos que recaíam sobre a massa da população foram severamente aumentados. Isso ocorreu de maneira mais clamorosa na tributação sobre imóveis. Em 2010, muitos egípcios sem nenhuma posse além do teto sobre a cabeça, vivendo de aposentadorias ou pensões de menos de cinquenta dólares por mês, viram-se repentinamente em face de exorbitantes tributos sobre seus lares. A consequência foi uma tal onda de protestos, com demandas e apelos para que o presidente interviesse, que Mubarak suspendeu a nova taxação dois meses antes da data prevista para que ela entrasse em vigor. Por volta de 2010 , acreditava-se amplamente que Mubarak não iria se recandidatar à presidência nas eleições de setembro deste ano, mas repassaria a candidatura a seu filho. A perspectiva de Gamal no poder, que não mais se afigurava como sucessor indiscutível, mas exercia poder absoluto com seus compadres, assustava muita gente. A vida já estava economicamente dificílima para a maioria dos egípcios. Como ficaria se não houvesse nenhum recurso de oposição a ele e a tudo o que ele vinha representando?

Em paralelo a essa mudança social, e associada a ela, houve uma alteração nas formas de repressão política empregadas pelo regime. Nos anos 1950 e 60 , as pessoas sabiam que somente seriam detidas ou torturadas se fossem politicamente organizadas. Os militares se encarregavam da repressão interna, que era brutal mas altamente direcionada. Nos anos 1970 e no início da década de 1980, essa função foi transferida do Exército para a polícia. A repressão passou a ser mais indiscriminada, mas ainda era exercida no âmbito de uma estrutura discernível e dentro de certos limites. Os que a comandavam eram coronéis ou capitães, pessoas com nomes, postos e rostos que de algum modo assumiam responsabilidade pelas decisões que tomavam, e para cair nas mãos delas ainda era preciso ter algum tipo de envolvimento político - agora não necessariamente organizado, mas que atravessasse uma "linha vermelha" ou contrariasse alguma autoridade. Nos anos 1990, porém, o regime estava tão confiante de que não enfrentava nenhuma contestação que tratava as críticas na imprensa, na televisão e posteriormente na internet como trivialidades inofensivas. Também era essa a atitude assumida pela polícia: a repressão a cidadãos no dia a dia era banal demais para ser executada por agentes uniformizados. Por que policiais despenderiam tempo e energia intimidando uns poucos estudantes, o eventual dirigente sindical de cabeça quente ou algumas ativistas pró-direitos humanos das mulheres para manter essa gente afastada das ruas?

Desse modo, auxiliares à paisana foram cada vez mais utilizados para cumprir essas tarefas. Sadat já havia lançado mão de marginais truculentos desse tipo nos anos 1970, mas em proporções muito 
pequenas - a fim de não comprometer a polícia, fazia-se passar investidas por manifestações de apoio popular ao regime. Mubarak os empregou em eleições parlamentares nos anos 1980. A partir dos anos 1990, porém, o recurso à contratação temporária desses capangas, presentes na folha de pagamento mas não nos quadros oficiais da polícia, tornou-se a norma, e com isso a repressão se tornou bem mais aleatória. Eles com frequência molestavam ou maltratavam gente pacata sem nenhum motivo político, apenas para fins de extorsão. Foi um caso trágico desse fenômeno difuso que acabou por desencadear o levante. Khaled Said tinha quase vinte anos e era um rapaz instruído, pertencente a uma boa família de Alexandria. No verão de 2010 [em 6 de junho], ele trocou algumas palavras com dois desses auxiliares de polícia num cibercafé, e em seguida eles simplesmente esmagaram seu rosto na calçada. Depois alegaram que ele era suspeito de porte de drogas e que antes que pudessem revistá-lo ele cometeu suicídio. Fotos dele logo estavam por toda parte na internet. Em Dubai, Wael Ghonim, diretor executivo do Google, criou um grupo no Facebook denominado "Todos somos Khaled Said" [We are all Khaled Said], pedindo a adesão de todo mundo que houvesse deparado com aquele tipo de barbárie. Dali a uns dois meses, mais de 100 mil pessoas haviam aderido. Essa foi a contingência que deu início a todo o movimento. Por trás dela estava a dupla deterioração - a exploração econômico-financeira e a roubalheira e a perseguição e a repressão arbitrárias - que tornou cada vez mais insuportáveis as vidas de egípcios que nada tinham a ver com política.

\section{Khaled Said foi assassinado no verão de 2010 . O que explica o momento da revolta seis meses depois?}

O dia 25 de janeiro é um feriado nacional que comemora a resistência heroica de policiais egípcios em Ismaília, cidade na zona do Canal de Suez, contra um destacamento britânico que lhes ordenou que entregassem suas armas naquele dia em 1952. Mais de quarenta policiais foram mortos e dezenas ficaram feridos naquilo que se tornou conhecido como o Dia da Polícia. A fim de sublinhar o contraste entre a polícia daquela época e a atual, o grupo "Todos somos Khaled Said" resolveu fazer uma manifestação nas proximidades da sede do Serviço de Segurança do Estado no centro do Cairo, na praça Tahrir. O grupo esperava reunir algo em torno de 5 a 7 mil pessoas, mas mesmo um contingente desses parecia demasiadamente improvável na ocasião. Sob Mubarak, as maiores manifestações nunca haviam passado de umas poucas centenas de pessoas. No entanto, com o estímulo da queda da ditadura tunisiana em 14 de janeiro e o apoio de outros grupos oposicionistas com base na internet, a convocação levou às ruas possivelmente umas 20 mil pessoas. 
Ao longo dos dois dias seguintes, não só os protestos continuaram como diversos grupos de oposição se juntaram para fazer uma mobilização maior. A polícia passou a lançar jatos d'água e gás lacrimogêneo contra os manifestantes. Em vez de fazer com que eles parassem, a brutalidade da polícia incitou outro protesto de grandes proporções após as preces de sexta-feira em 28 de janeiro, o chamado "dia da fúria". Confluindo a partir de diversos pontos de concentração e ganhando ímpeto à medida que marchavam em direção à praça Tahrir, massas acumulando-se como bola de neve num contingente de cerca de 80 mil pessoas agora estavam dispostas a enfrentar a polícia. Aturdida com a magnitude e a persistência dos manifestantes, a polícia acabou sendo sobrepujada. Foi um brusco despertar. De repente a polícia se confrontou com a realidade de que, em consequência das transfigurações que descrevi, não estava equipada nem treinada para lidar com sublevação em massa. O que se seguiu foi uma batalha épica na ponte Qasr al-Nil, que liga a praça Tahrir à porção oeste da cidade, de onde vinha a maioria dos manifestantes. Se vocês assistirem aos vídeos dessa batalha, poderão constatar como a repressão se mostrou incompetente e desorganizada: a polícia manobrando um punhado de veículos blindados de maneira descoordenada, ziguezagueando em meio às massas, tentando atingir pessoas, disparando projéteis de vários tipos e em seguida batendo em retirada com tiros e jatos d'água contra as pessoas, o que só as deixava mais enfurecidas. Depois de quase duas horas de conflitos, blindados de transporte de tropas estavam tombados pelos manifestantes e a polícia se retirara - abandonando não só a ponte como todo o centro da cidade - , enquanto as massas incendiavam a sede do PDN e ocupavam a praça. A essa altura, o ministro do Interior informou Mubarak que a situação estava fora de controle e avisou-lhe que o Exército precisaria intervir. Tropas foram posicionadas em torno de locais estratégicos e de edifícios governamentais em vários pontos da cidade, anunciou-se um toque de recolher e na manhã seguinte os militares estavam por toda parte.

Quais eram as forças por trás da mobilização de 28 de janeiro e em que medida elas estavam coordenadas entre si?

Pode-se dizer que seis grupos propulsionaram o movimento. Dois se baseavam em redes do Facebook. O primeiro era o grupo "Todos somos Khaled Said", do qual já falei. O segundo era o Movimento Jovem 6 de Abril [April 6 Youth Movement], que surgiu para dar apoio a uma greve geral convocada para essa data em 2008 . Apenas uma das pequenas cidades industriais da região do Delta atendeu à convocação, e ali os trabalhadores foram brutalmente reprimidos, com alguns feridos a bala e mortos. No ano seguinte, os organiza- 
dores do apoio criaram uma página no Facebook com a identidade Movimento Jovem 6 de Abril e pediram a todos que naquele dia ficassem em casa, em vez de se concentrar nas ruas. A despeito da vigilância da polícia, em 2010 o grupo tinha cerca de 70 mil adeptos. Assim, havia sido formado há mais tempo do que a rede criada por Wael Ghonim e tinha um perfil mais político, combinando posicionamentos trabalhistas e liberais. Embora uma manifestação em massa fosse contrária à sua estratégia de greve "fique em casa", o movimento decidiu juntar forças com o "Todos somos Khaled Said" para a mobilização de janeiro.

Um terceiro grupo importante foi a ala jovem da Irmandade Muçulmana, que surgira três anos antes. Na Irmandade, reformistas vinham tentando mudar as posições e as estratégias tradicionais do movimento. Sua meta era formar um partido político com organização e líderes próprios, que fosse apenas remotamente ligado ao movimento cultural em geral da Irmandade Muçulmana. A campanha desses reformistas se intensificou em face das notícias de que o avanço do movimento nas eleições parlamentares de 2005, nas quais seus membros conquistaram 88 assentos [20\% do total], fizera parte de um plano do Serviço de Segurança do Estado para dissuadir os Estados Unidos de pressionar Mubarak pela democratização do país. Em outras palavras, os líderes do movimento entraram no jogo do regime de bom grado, assumindo o desonroso papel de espantalhos. Os reformistas sofreram um forte revés em 2010 , quando um conservador da velha guarda [Mohammed Badie] foi eleito guia supremo da organização e não atendeu aos pedidos de grupos oposicionistas seculares para que ela se juntasse a eles no boicote às eleições parlamentares fraudulentas promovidas pelo regime. Para piorar as coisas, a cumplicidade não foi recompensada: a Irmandade não amealhou sequer um assento na nova legislatura. A partir de então, a ala jovem desacatou abertamente o conselho diretivo da Irmandade, exortou os reformistas a deixá-la e a constituir um partido político de qualquer jeito. Quando foi emitida a convocação para uma manifestação no dia 25 de janeiro, o grupo decidiu então integrá-la.

Um quarto grupo era composto de representantes daquilo que se poderia chamar de uma "nova esquerda" no Egito. Eram sobretudo esquerdistas jovens e de meia-idade, cujas relações com os líderes originais do movimento comunista não eram diferentes daquelas da ala jovem da Irmandade com seu conselho diretivo. Os comunistas veteranos, que remontam a meados do último século, são homens idosos que há muito tempo fizeram as pazes com o regime. A justificativa deles era a de que a islamização representaria a maior ameaça ao Egito e o comprometimento com o secularismo os vinculava ao segmento dominante, supostamente liberal. Por 
isso consentiram em atuar conforme os ditames do regime, o que lhes permitia escrever e discursar mas os impedia de construir uma base autêntica no âmbito da classe operária. Para os esquerdistas mais jovens, porém, havia outras ameaças além da islamização, mais especificamente os desenfreados abusos neoliberais. Para estes, a prioridade era organizar a resistência nas fábricas. Assim, há cerca de cinco anos eles vêm tentando desenvolver uma força própria, criando, entre outras coisas, um periódico chamado Al-Bousla (que em árabe significa "a bússola") para congregar os segmentos mais ativos da esquerda egípcia. São em sua maioria intelectuais urbanos, muitos deles professores assistentes: jovens historiadores, cientistas políticos ou sociólogos.

Um quinto grupo se reuniu em torno de Mohamed El-Baradei, ex-chefe da Agência Internacional de Energia Atômica, sediada em Viena, que voltou para o Egito em 2010 e anunciou que seria candidato a presidente se a Constituição fosse alterada de modo a possibilitar eleições livres. Comenta-se que Baradei teve um desentendimento com Mubarak, pois como embaixador ele foi a certa altura o candidato oficial do Egito ao posto diretivo da Agência, mas na última hora o presidente o preteriu por outro candidato. Mesmo assim Baradei foi eleito e depois disso se manteve distante do regime, muito embora Mubarak tivesse de tratá-lo com respeito em razão de seu prestígio internacional. Ao voltar para o Cairo, ele atraiu jovens privados de direitos civis em torno de uma demanda por reformas que não tinha contornos bem definidos, criando um grupo denominado Associação Nacional pela Mudança — uma miscelânea cujo espectro ia de liberais e de islamitas progressistas a um punhado de esquerdistas, alguns filiados a partidos políticos, em particular a Frente Democrática, e muitos deles independentes. Um dos principais porta-vozes desse grupo era o filho de Yusuf Al-Qaradawi, um clérigo proeminente; outros eram jovens empresários e executivos. Contudo, Baradei ainda passava a maior parte de seu tempo na Europa, desempenhando mais o papel de inspirador do que de efetivo líder do grupo. A consequência era um grupo de jovens exaltados que faziam o que desse na telha. Desse modo, a conturbação que estava se formando em janeiro de 2011 acabou encontrando mais um colaborador.

Por fim, havia um sexto grupo constituído por uma conjunção de ativistas pró-direitos humanos que militavam em organizações egípcias ou internacionais, tais como a Anistia Internacional e a Human Rights Watch. Era um agrupamento muito eclético, composto de jovens reunidos tão somente pelo fato de que não haviam encontrado nenhuma organização política capaz de mobilizá-los para contestar o regime mais diretamente. 
A característica comum desses seis grupos é que todos estavam desiludidos com as tradicionais alternativas à ditadura. Eles também se beneficiaram das tecnologias de comunicação contemporâneas, evidentemente. Nas grandes cidades há cibercafés por toda parte, e até os pobres possuem celulares. Isso é sobretudo uma cultura da juventude, mas está amplamente disponível em todas as classes sociais. No entanto, cabe notar que os sites de redes sociais só cumpriram um papel relevante nas etapas preliminares do levante. Uma vez que a bola de neve começou a rolar, a importância deles diminuiu em favor das mídias mais tradicionais, como a televisão e o rádio.

A partir da manifestação de 28 de janeiro, a praça Tahrir foi continuamente ocupada por manifestantes. Em $1^{\circ}$ de fevereiro, uma manifestação ainda maior realizada ali exigiu a renúncia de Mubarak. No dia seguinte, capangas da polícia liberados para atacar a ocupação foram repelidos da praça. Seguiu-se uma mobilização bem maiorno dia 4. Porvolta do dia 7 as greves haviam se disseminado. No dia 10 o Conselho Militar Supremo se reuniu pela primeira vez desde 1973. Mubarak caiu no dia 11, em consequência de um levante popularque se expandia incessantemente. Como se pode descrever a composição social dele?

As multidões da praça Tahrir representavam a massa crítica da sociedade egípcia, abrangendo estratos que iam da classe média baixa à classe média alta. Ali se podia encontrar desde homens de negócios abastados e corretores da bolsa de valores até balconistas e lojistas, porteiros e vigias. Nessa gama havia pessoas de todas as idades, desde avôs até crianças pequenas, de ambos os sexos e das duas principais religiões. As mulheres se mobilizaram desde o primeiro dia; mães idosas usando véus e ativistas sem véus postavam-se de mãos dadas. Um aspecto bastante notável nas aglomerações foi a absoluta ausência de assédio sexual, uma questão que nos últimos anos vem se agravando no cotidiano das ruas egípcias. De modo similar, não houve nenhuma tensão entre muçulmanos e coptas. Já faz um bom tempo que o Ministério do Interior vem sub-repticiamente insuflando antagonismo entre as duas comunidades, mas desde o primeiro dia do movimento podia-se ver cristãos dando-se as mãos e formando um círculo em torno dos muçulmanos quando eles faziam suas preces, bem como muçulmanos formando um cordão em torno dos cristãos quando eles celebravam missas na praça.

\section{E a classe operária?}

Com relação à distribuição de renda, os trabalhadores fabris estão entre os estratos da classe média baixa da sociedade egípcia, e também se mobilizaram desde o primeiro dia. Não na praça Tahrir, mas 
em Alexandria, que tem muitas fábricas de grande porte em seus subúrbios, e em diversas cidades do país. Estima-se que a revolta inteira possa ter envolvido algo entre 10 e 15 milhões de pessoas, das quais no máximo 5 milhões no Cairo. Na participação dos operários no movimento, manifestações precederam as greves. Houve uma imensa onda de distúrbios populares pelo país em todo tipo de contexto econômico, desde as cidades de Port Said, Ismaília e Suez, na zona do Canal, até os oásis turísticos do deserto ocidental. Nos oásis de Al-Wahat, onde um hotel de luxo está sendo encravado nas montanhas a um custo enorme e milhões estão sendo gastos em profusas amenidades turísticas, enquanto a população local não recebe praticamente nada, o furor coletivo foi tão intenso que o chefe de polícia da área teve de ser transferido por atirar em manifestantes. Repressão e exploração foram os fósforos que acenderam o fogo da reação popular - a repressão afetando os segmentos mais abastados da classe média, e a exploração os menos privilegiados.

As greves passaram a ocorrer quatro dias antes da queda de Mubarak. Elas vinham sendo frequentes nos últimos anos: estima-se que cerca de 2 milhões de trabalhadores tenham se envolvido em algum tipo de atividade grevista ao longo da década passada. Mas de modo geral as greves eram apolíticas, restringindo-se a reivindicações salariais, protestos contra demissões, campanhas por aposentaria com menor tempo de serviço. Ademais, eram estritamente locais. Jamais houve tentativa de qualquer mobilização reivindicatória de âmbito nacional, em parte porque a vigilância era tão rigorosa que os trabalhadores só organizavam greves entre aqueles que conhecessem e em quem confiassem, que morassem nas suas vizinhanças, perto da fábrica. Faltava-lhes a confiança necessária para fazer greves nacionais, já que não podiam estendê-la a trabalhadores de outros distritos ou províncias. Desde que as reivindicações fossem apenas por modestas melhorias trabalhistas, o regime as tolerava (Gamal não queria assustar investidores estrangeiros com repressões armadas contra grevistas), podendo até mesmo tratá-las como uma espécie de resquício tardio do contrato social que de resto ele invalidara. Uma vez iniciado o levante, porém, qualquer greve adquiria uma força política e impulsionava a revolta. Nos últimos dias antes da queda de Mubarak, líderes grevistas começaram a demandar a criação de uma confederação sindical independente no lugar das centrais sindicais de fachada da ditadura. Tudo isso certamente abalou o regime. Contudo, as conexões entre as lideranças grevistas e as organizações que se mobilizaram na praça eram muito tênues, e seria um equívoco imaginar que a movimentação grevista foi a gota d'água. 
E quanto ao subproletariado dos bairros pobres do Cairo e de outras grandes cidades?

Muitos temiam que esses paupérrimos entre os pobres pudessem um dia perpetrar uma jacquerie egípcia. No Cairo e arredores, calcula-se que eles são entre 5 e 6 milhões de pessoas vivendo em condições subumanas - habitando favelas sem água encanada, sem energia elétrica, sem rede de esgotos, sem escolas. A palavra árabe para esses lugares é ashwa'iyyat, derivada de uma raiz que significa "ao acaso". Os moradores dos ashwa'iyyat são gente ao acaso: seres humanos contingenciais para aqueles com vida estabilizada, a quem atemorizam como gente completamente destituída que sai de seus habitats sinistros para invadir a cidade ordenada, falando um árabe estranhamente distorcido, procurando emprego desesperadamente, roubando mercadorias e importunando cidadãos para então se recolher a seu mundo de trevas. Eles não poderiam um dia saquear e incendiar a cidade?

Afortunadamente, essa ameaçadora massa humana ficou completamente fora da revolta, o que provavelmente contribuiu para seu caráter civilizado e pacífico. No dia anterior à queda de Mubarak, ativistas de Alexandria estavam planejando convocar esse segmento para engrossar ainda mais os números do movimento. Se tivessem feito isso, sem dúvida teriam espalhado pânico por todo o país. No outro extremo da escala social, a camada realmente rica da sociedade egípcia - a elite dos altos negócios - também não teve, é claro, nenhuma participação no movimento. Essas pessoas, as principais beneficiárias do regime, estavam obviamente por trás de Mubarak e ficaram com os motores de seus jatinhos ligados, prontas para se mandar caso fosse necessário.

Mas os moradores dos ashwa' iyyat são tão homogêneos assim? Afinal, estima-se que eles são um quinto do total da população egípcia. Estudos sociológicos não mostram que entre eles há pessoas instruídas - jovens ou não tão jovens - que não têm condições financeiras de morar no centro da cidade mas não são paupérrimas?

Sim. Os habitantes das periferias das grandes cidades se dividem no mínimo em dois segmentos distintos, que de modo geral correspondem a bairros diferentes. De um lado, há pessoas que deixam de ter condições financeiras de continuar morando na cidade em sentido estrito e se mudam para locais que na verdade são bairros históricos. No caso do Cairo eles existem no mínimo desde o século XVIII, e se deterioraram bastante nos últimos trinta anos ou algo assim. Ainda têm redes sociais fortes e são bem politizados, mas estão terrivelmente decaídos por causa da negligência do Estado. De outro lado, temos as favelas propriamente ditas, constituídas de barracos cons- 
truídos ao acaso nos últimos dez ou quinze anos. Não têm nenhum serviço ou equipamento público e são apinhadas de gente extremamente pobre, proveniente de localidades rurais ou subdesenvolvidas do interior do país.

Esses habitantes dos ashwa' iyyat são mesmo o equivalente contemporâneo das classes dangereuses do imaginário burguês do século XIX? Eles constituem mais de um quarto da população da região metropolitana do Cairo. Visto que foram excluídos de antemão da mobilização política como inconvenientes para qualquer manifestação, como pode haver a menor esperança de uma democracia egípcia?

Se excluirmos os bairros históricos, essa proporção fica significativamente mais baixa: talvez 2 ou 3 milhões de pessoas. Isso posto, uma política revolucionária que pretenda ser realista tem de levar em conta os temores e as apreensões prevalecentes numa sociedade de classes. A organização do levante veio à tona em questão de dias, e permaneceu tênue e improvisada. Ela não conseguiria de jeito algum canalizar uma explosão coletiva vinda dos bairros miseráveis, que só ajudaria a ditadura a se encastelar. Também correria risco se houvesse um desencadeamento de criminalidade ou saques, já que a certa altura os policiais se retiraram das ruas. É preciso admitir que foi sorte que nada disso tenha acontecido. Por certo, a ausência dessa massa de pobres também foi uma expressão de seu dramático isolamento do resto da sociedade. A prioridade é reintegrá-los à vida urbana. A maioria dos candidatos presidenciais que emanaram do levante, se não todos eles, têm afirmado que o primeiro item de seu programa de governo será estender serviços públicos e infraestrutura - habitação decente, água potável, escolas, policiamento - aos ashwa'iyyat, de modo a restituir as periferias às cidades a que pertencem.

Ao que tudo indica, o campesinato foi o outro grande segmento a permanecer passivo durante o levante. Isso era de esperar?

As circunstâncias no campo são fruto de um longo processo histórico. Nos anos 1950, quando Nasser chegou ao poder, os camponeses eram no mínimo $80 \%$ da população, e ele cuidou para que eles jamais viessem a ser politicamente mobilizados. É certo que ele foi igualmente precavido com os operários, mas estes ao menos se concentravam nas grandes cidades, onde podiam ser vigiados e controlados. Os camponeses eram muito mais numerosos e difusos, e não se podia lidar com eles do mesmo jeito. Nasser instituiu uma reforma agrária, mas ela não levou a uma redistribuição de benefícios para a maioria dos camponeses. Os grandes proprietários de terras foram avisados de que seria imposto um limite máximo à área de suas propriedades, mas tiveram tempo de sobra para dispor delas, transferindo-as para parentes 
ou vendendo-as no mercado livre. O resultado disso foi o surgimento de um novo segmento de proprietários de terras medianos - detendo áreas entre vinte e cem feddans ${ }^{1}$ - integrado ao partido do regime, que à época era a União Socialista Árabe. O campesinato foi basicamente transferido da tutela dos grandes proprietários de terras para a desse novo estrato. Dependentes desses exploradores, os camponeses ficaram alienados da vida do Estado.

No entanto, seus arrendamentos foram protegidos: eles não podiam ser expulsos de seus lotes pelos proprietários. Em 1997, porém, começou a vigorar uma lei, aprovada por Mubarak no início da década, que permitia aos proprietários despejá-los. A consequência foi uma onda de revoltas camponesas ao longo dos dois anos seguintes, com milhares de aldeões se recusando aos despejos, ateando fogo a plantações e atacando seus opressores. Tropas das forças de segurança federais foram enviadas, povoados inteiros foram arrasados e a sublevação foi contida. Depois disso, muito pouco se ouviu falar do campesinato. Se para os ativistas da oposição era difícil se comunicar com os operários, era ainda mais difícil fazer contato com os camponeses, ainda mais despolitizados à força. Assim, não é de surpreender que nas três abruptas semanas do levante a população rural — ainda que tacitamente gratificada com a revolta — tenha cumprido um papel tão pequeno.

\section{Há diferenças regionais significativas no campo?}

Historicamente, o país sempre se dividiu em duas partes, o Baixo Egito e o Alto Egito. A primeira se estende do sul da capital até o Mediterrâneo, e contém cerca de $85 \%$ da população; a segunda se estende em direção ao sul até a fronteira com o Sudão. Essa última região, comumente conhecida como Sa'id, poderia ser vista como uma versão egípcia da Sicília, com tradições de honra familiar, vendetas, tráfico de armas e drogas à maneira da máfia. À diferença do resto do país, a população rural costuma andar armada, e tem motivos de queixa particulares contra o regime. Embora tenha comparativamente mais coptas, o Sa' id concentrou a maior parte da militância islâmica desde o fim dos anos 1970 até meados dos anos 1990. Ademais, o Estado frequentemente tem indicado para o sul seus governadores mais severos ${ }^{2}$, buscando assim exercer um controle mais rígido sobre a região, ao mesmo passo que investe muito menos aí do que no norte, justamente por causa de sua característica insubordinada. Poucas lágrimas terão sido ali derramadas pela defenestração de Mubarak.

\section{O REGIME}

Mubarak se foi, mas os aparatos em que sua ditadura se apoiava não desapareceram. Atualmente as Forças Armadas detêm poder absoluto,
[1] Feddan: unidade de medida de área usada no Egito, no Sudão e na Síria, equivalente a 0,42 ha. [N.T.]

[2] No sistema de governo egípcio atual, os governadores de províncias são nomeados pelo presidente. [N.T.] 
sob a forma do Conselho Militar Supremo. Como os militares egípcios podem ser caracterizados e que papel eles deverão desempenhar agora? Quando um regime se estabelece por meio de força militar, seja mediante golpe ou conquista, geralmente se distribui numa estrutura de poder tripartite. Há uma divisão de trabalho entre seus três componentes, que se cristalizam em instituições distintas. $\mathrm{O}$ primeiro componente desse "triângulo do poder" é constituído por aqueles que se encarregam da gestão governamental por meio de um aparato político, no mais das vezes composto de uma presidência (ou uma monarquia) e um partido dominante. O segundo é constituído por oficiais militares que cuidam da repressão interna por meio de um complexo de segurança, cujos setores abrangem a força policial, o serviço de inteligência e forças paramilitares. O terceiro é constituído por aqueles que retornam aos quartéis e continuam a representar os militares propriamente ditos. Com o tempo, esses componentes produzem agendas distintas, já que as instituições elaboram identidades próprias, desenvolvem interesses corporativos específicos e moldam seus membros à sua própria imagem, o que os analistas de modo geral equivocadamente subestimam ou generalizam. Assim, no caso do Egito eles tendem a falar de Mubarak, de Omar Suleiman e de Ahmed Shafiq como figuras militares, uma vez que Mubarak foi chefe da Aeronáutica há 35 anos, Suleiman foi general do Exército há mais de vinte anos e Shafiq comandou a Aeronáutica há dez anos. No entanto, essa forma de classificação é ilusória. Uma vez que agentes como esses passam a integrar o aparato político ou de segurança de um regime, não mais representam os interesses das Forças Armadas como uma instituição.

Por temperamento e formação, os militares não são particularmente inclinados a exercer nem o governo direto, nem a repressão interna. Seus interesses tendem a recair na intensificação de seu poder de fogo e de sua prontidão para o combate de modo mais amplo, bem como na situação econômico-financeira das Forças Armadas. No mais das vezes, a exemplo da Turquia ou da América Latina, o oficialato se contenta em instituir um processo político em que haja competição partidária e então recua para atuar como guardião do sistema por ele recém-criado, somente intervindo, quando necessário, mediante advertências ou golpes "corretivos" e circunscritos.

Muito diversa é a trupe da segurança, uma criatura anômala que só prospera num ambiente autoritário. Se o regime se democratiza, sua influência diminui e ela acaba por ficar totalmente desvalorizada. Seus membros percebem que serão responsabilizados pelas atrocidades que perpetraram. Em comparação com os militares, o pessoal do aparato de segurança se envolve bem mais em violações de direitos humanos e é bem menos capaz de obter anistia. Quando há 
uma mudança democrática, os novos governantes evitam entrar em conflito com os militares mas não hesitam em indiciar autoridades da segurança. Dessa maneira, os órgãos de segurança, à diferença dos militares, sempre se empenham pela continuidade do autoritarismo.

Nesse sistema de poder, a liderança política geralmente fica suspensa no meio. Ela é vulnerável, já que não tem como reprimir a população sem o apoio do aparato militar ou do complexo de segurança. Ao mesmo tempo, ela não necessariamente requer um cenário ultra-autoritário permanente: pode continuar se aferrando ao poder na medida em que faça concessões circunstanciais que levem à chamada "semiliberalização".

Em razão dessas variadas propensões e potencialidades, os três componentes desse tipo de regime tanto cooperam como competem entre si; seus interesses tanto se justapõem como divergem o tempo todo, de acordo com os desdobramentos nacionais ou internacionais. O que complica o quadro ainda mais é que nenhum desses três componentes tem caráter monolítico; todos eles têm suas subdivisões e tensões internas.

\section{Os militares egípcios se enquadram nesse esquema?}

Sob Nasser, como mencionei, os militares a princípio se encarregavam da repressão interna. Mas após a Guerra dos Seis Dias, em 1967, o aparato político resolveu não mais tolerar os caprichos dos militares e começou a isolá-los politicamente sob o pretexto de profissionalizá-los. Esse processo de isolamento foi intensificado por Sadat durante a Guerra Árabe-Israelense de 1973. Mubarak o aprofundou ainda mais nos anos 1980. O último líder carismático dos militares egípcios, o marechal Abu Ghazala, foi afastado em 1989. Desde então as Forças Armadas ficaram politicamente neutralizadas.

Atualmente o contingente militar do país está em mais de 450 mil homens, dos quais cerca de 300 mil são recrutas. Todos os egípcios do sexo masculino prestam serviço militar por um ano caso tenham feito ensino superior e por três anos caso não tenham, a menos que possuam isenção médica ou sejam arrimo de família. Os recrutas geralmente não têm muito que fazer em matéria de treinamento de combate - podem acabar dando tiros de espingarda algumas vezes, mas só isso. Fazem basicamente serviços logísticos e de office boy: limpeza, entregas, compras para os oficiais. A verdadeira capacidade das Forças Armadas está em seus oficiais de carreira. A posição deles no sistema dominante, assim como na sociedade em geral, é com frequência mal compreendida fora do país. Ela é bem menos privilegiada do que muitos observadores imaginam. No campo político, sob Mubarak a influência das Forças Armadas foi bem menor do que a do partido do governo e dos órgãos de segurança. No aspecto social, 
a situação dos oficiais militares se depreciou quando comparada à de seus colegas da polícia e dos quadros do PDN. Ninguém os considerava donos do país.

Economicamente, os oficiais ganharam alguma autonomia. Concedeu-se a eles controle sobre seus empreendimentos e muitas terras, para que se mantivessem dóceis. Sadat e Mubarak compreenderam que se abrissem a economia não poderiam deixar os militares à mercê das forças do mercado: era preciso assegurar-lhes autossuficiência. Assim, proporcionaram-lhes negócios rentáveis que pudessem lhes garantir uma vida decente: um carro, um apartamento, uma casa de campo, e assim por diante. Mas não se trata de nenhum império econômico-financeiro nas proporções daquele erigido pelo Exército turco, por exemplo. São empreendimentos bem mais modestos. As instalações militares são bastante precárias se comparadas com o que está disponível nos bairros ricos do Cairo. Os oficiais não enriqueceram escandalosamente. O que se ganha no Exército ou na Aeronáutica parece insignificante em comparação com o que se pode obter como oficial de polícia graduado ou membro do partido do governo. Sob Mubarak, o ministro do Interior acumulou mais de 1 bilhão de dólares em sua conta bancária. $\mathrm{O}$ ministro da Defesa não poderia nem sonhar com essa soma de dinheiro.

Em termos estratégicos, ademais, por trás de todo o seu armamento moderno os militares egípcios vêm passando por uma crise de identidade. Após a Guerra Árabe-Israelense, Sadat sabia que para evitar que eles ficassem demasiadamente frustrados ele teria de proporcionar às Forças Armadas uma considerável satisfação simbólica. Assim, cuidou para que os Estados Unidos lhes fornecessem treinamento e armas de ponta, propiciando-lhes o prestígio de figurarem como a décima maior força militar do mundo. Mas acabaram por perceber que essas coisas eram apenas de fachada, e se sentiram totalmente supérfluos. Eles não têm nenhuma capacidade de projetar o Egito como um poder militar estratégico sobre qualquer país do entorno - não só Israel, mas também os demais países vizinhos. Após a primeira Guerra do Golfo, falou-se na possibilidade de que as forças egípcias fizessem parte do sistema de segurança do Golfo (aquilo que foi denominado como a "Declaração de Damasco", de 1991), mas os americanos disseram que não, que iriam lidar com aquilo instalando suas próprias bases nos países do Golfo. Depois surgiu a questão de que o Egito pudesse desempenhar um papel mais ativo na estabilização da Faixa de Gaza ou do Líbano, o que também não deu em nada. Mas foi a divisão do Sudão, algumas semanas antes da revolta de janeiro, que abalou as Forças Armadas de cabo a rabo. O Sudão ocupa um lugar central na doutrina de segurança nacional do Egito. A secessão do sul ameaça 
o controle egípcio sobre as nascentes do Nilo. Mas uma vez mais disseram aos militares que aquela era uma zona de influência americana. Generalizou-se então entre os oficiais a sensação de que se alistar no Exército significaria construir estradas, fazer pescarias ou cumprir quaisquer outras funções afora as de soldado. $O$ primeiro capitão a se fraternizar com os manifestantes na praça começou a se queixar disso: "O que efetivamente estamos fazendo? Qual é nossa missão? O que fizemos em Gaza ou no Sudão?".

Esse mal-estar ficou evidente depois da renúncia de Mubarak. Por mais de trinta anos, desde a queda do Xá, o regime jamais permitira que navios do Irã, tanto civis como militares, atravessassem o canal de Suez. Passado um mês após a saída de Mubarak, os militares egípcios deram passagem a dois navios de guerra iranianos com destino à Síria, recusando-se a atender solicitações dos Estados Unidos e de Israel de que os navios fossem interditados ou no mínimo revistados. Os militares não tiveram a intenção de queimar suas pontes com nenhum dos dois países. Apenas enviaram a mensagem de que iriam decidir o que é de interesse nacional, assim como fazem os militares da Turquia, por exemplo. Foram dados outros passos nessa direção em meados de março, quando o Conselho Militar Supremo enviou o novo diretor do Serviço de Inteligência à Síria e ao Qatar para discutir meios de intensificar relações internacionais estratégicas. Sabe-se que a Síria e o Qatar, em conjunto com a Turquia e o Irã, fazem parte de um novo bloco de poder regional que está buscando adquirir uma relativa autonomia em relação à agenda ocidental, sem necessariamente se contrapor a qualquer uma das potências ocidentais.

Nisso tudo não há nenhum sinal — por enquanto — de quaisquer divisões sérias no interior do aparato militar egípcio. Se tivesse havido cisões significativas entre patentes superiores e inferiores durante a revolta popular, teríamos visto algum indício disso. Teríamos visto, por exemplo, patentes inferiores desacatando ordens para acabar com as manifestações, ou então dezenas de soldados e de oficiais iniciantes rompendo fileiras e se juntando aos manifestantes - o tipo de fraternização em grandes proporções que ocorreu durante a Revolução Iraniana, por exemplo. Não vimos nada disso no Egito. Até agora os militares vêm se pronunciando com uma voz unificada, tanto entre as forças como entre suas patentes.

Sob Mubarak, como os aparatos político e militar se conectavam dentro do regime?

Desde 1967 o presidente é o comandante em chefe das Forças Armadas. Ele nomeia o ministro da Defesa, os chefes de todas as forças e o estado-maior. Também tem diretamente sob si a Guarda 
Republicana (chamada pela imprensa de Guarda Presidencial), que constitui uma quinta força militar ao lado do Exército, da Marinha, da Aeronáutica e da Defesa Antiaérea. A Guarda permaneceu bem pequena por uma década e meia após sua criação em 1953, com um efetivo que não passava de umas poucas centenas. Quando Nasser começou a marginalizar os militares politicamente - em seguida à derrota de 1967 - elevou aquele corpo de elite à potência de um batalhão. Depois Sadat o expandiu à razão de uma brigada composta de algo entre 15 e 30 mil soldados (os números não são fidedignos), equipada com blindados pesados. À diferença de outras unidades militares, a Guarda não fica posicionada em quartéis fora da cidade, mas nas proximidades dos vários palácios presidenciais, e seu comandante sempre foi escolhido por demonstrar especial lealdade ao governante. Em 11 de fevereiro os manifestantes temiam que Mubarak mobilizasse a Guarda para sufocar a revolta, mas ela acabou por ficar ao lado dos militares, não do presidente.

\section{Qual é o peso das forças de segurança em comparação com o Exército?}

Quando Nasser assumiu o poder, encarregou um de seus colaboradores mais próximos, Zakaria Mohieddin, de promover a Seção Especial do Ministério do Interior, criada pelos britânicos, a um renomeado Departamento de Investigações Gerais responsável pela vigilância e dispersão de qualquer atividade política, com o auxílio do recém-criado Serviço de Inteligência Geral. Mas o Exército decidiu carregar nos ombros a tarefa da manutenção do regime. Sob seu carismático comandante, o marechal Amer, a Inteligência Militar, a Polícia Militar e as prisões militares desempenhavam o papel principal no campo da segurança interna. Após a guerra de 1967, quando Nasser buscou cercear o Exército, a Inteligência Militar foi circunscrita a espiar militares de outros países, o Serviço de Inteligência Geral foi redirecionado para atividades de espionagem de estrangeiros e contrainteligência interna (visando agentes inimigos no Egito) e o Departamento de Investigações Gerais foi reconduzido ao controle exclusivo da repressão interna.

Então Nasser decidiu que precisava de outro organismo para controlar as ruas e criou as Forças de Segurança Centrais, com base em alistamento militar obrigatório tal como o Exército e com o mesmo efetivo, de 300 mil homens. Seu trabalho seria manter a ordem e proteger locais estratégicos - os ministérios, o parlamento, embaixadas, bancos, o edifício da televisão. Assim, a repressão interna passou a ter uma cabeça e um braço; a cabeça era o Departamento de Investigações Gerais e o braço eram as Forças de Segurança Centrais. Sadat promoveu o primeiro a Serviço de Investigações de Segurança do Estado - nossa ss - e também fortaleceu as Forças de 
Segurança Centrais. Sob Mubarak, o pessoal recrutado para as operações de repressão interna era estimado sob a cifra heroica de um efetivo de 2 milhões. Desse total, porém, 1,5 milhão eram capangas ou informantes contratados sem postos nem uniformes, não raro indivíduos com ficha criminal que fecharam acordos com as autoridades - eles não faziam parte nem dos órgãos policiais em sentido estrito, nem das Forças de Segurança Centrais, nem da ss. Por mais que esse cômputo seja exagerado, a rédea solta de tantos indivíduos com relações escusas com a polícia aterrorizava os cidadãos.

Se excluirmos esse contingente, ficaremos com um aparato de segurança de cerca de 400 mil homens, dos quais 300 mil são recrutas armados com cassetetes, mas encabeçados por uma elite habitualmente chamada de Forças Especiais, equipada com veículos blindados, balas de borracha, mangueiras de jato d’água e gás lacrimogêneo para controlar tumultos. Em segundo lugar há cerca de 70 mil policiais propriamente ditos, lidando com drogas, prostituição, turismo etc. Por fim, o Serviço de Segurança do Estado, que é a força mais letal, tem cerca de 3 mil agentes, que contam com as mais modernas técnicas para detecção de dissenso político e tortura de detentos.

E o organismo partidário da ditadura? O PDN estava lado a lado com o Partido Trabalhista inglês, o Partido Socialista francês, o Partido Social-Democrata alemão e as demais entidades da social-democracia europeia na Internacional Socialista. Que espécie de estrutura é essa? Em 1953, antes de se tornar primeiro-ministro, Nasser resolveu formar o que chamou de Concentração pela Libertação, um vago movimento de massas mais voltado a solapar do que a suplantar todas as outras forças políticas da época. Cinco anos depois ele converteu aquilo na União Nacional, para realizar manifestações de apoio ao regime, amealhar os votos necessários caso fosse preciso promover eleições e plebiscitos e atuar genericamente como uma caixa de ressonância dele na sociedade. Ele incumbiu alguns de seus oficiais mais próximos de transformar isso num partido, que se constituiu em 1962 sob a denominação União Socialista Árabe. Mostrara-se impossível afastar Amer da chefia do Exército, e Nasser queria suplementar seu carisma e sua popularidade com uma organização política arraigada como um contrapeso aos militares. Nominalmente, o objetivo era mobilização em massa, mas na prática a União Socialista Árabe simplesmente se entranhava nas estruturas de poder existentes no campo, que ainda concentrava três quartos da população egípcia, cooptando proprietários de terras medianos - que eram as figuras economicamente dominantes nos povoados - para arrebanhar votos dos camponeses. 
Nas cidades, Nasser havia contado com capitalistas durante toda a década de 1950, mas eles continham seus investimentos porque não confiavam nos militares. Com a onda de estatizações em 1961, a maioria desses capitalistas se tornou parte integrante da máquina estatal. O exemplo mais conhecido é Osman Ahmed Osman, um magnata da construção civil que era o homem mais rico do país: quando sua empresa foi estatizada ele se tornou seu presidente, trabalhando para o governo. Uma vez incorporado à burocracia do Estado, esse segmento também se tornou um componente fundamental da União Socialista Árabe. Evidentemente, o partido não tinha nada de socialista nem nada que tivesse a ver com mobilização em massa. Sua função era meramente congregar a burocracia e os trabalhadores do setor público, de um lado, e os camponeses, de outro, para dar apoio clientelístico ao regime.

Essa foi a estrutura que Sadat herdou nos anos 1970. Perto do fim da década ele decidiu criar uma fachada mais democrática, permitindo que algumas pessoas com tendências esquerdistas formassem o partido Tagammu [Unionista Progressista Nacional] e outras com tendências mais liberais atuassem nos partidos Wafd [da Delegação] e Liberal, como decoração para um sistema em que o partido do governo renasceu em 1978 como Partido Democrático Nacional, com as mesmíssimas redes de patronagem de antes. No devido tempo, isso foi levado adiante por Mubarak. Mas no final dos anos 1990, depois que a economia foi aberta e o regime passou a buscar atrair investimentos estrangeiros, foi preciso fazer uma nova plástica. Gamal Mubarak desempenhou um papel fundamental nessa circunstância. Seu círculo o persuadiu de que ele conseguiria mudar o PDN se encostasse os tecnocratas que o encabeçavam - os quais, de maneira típica, haviam enriquecido com propinas e comissões por negócios de intermediação - para dar vez a autênticos homens de negócios que fossem mais jovens, mais instruídos e acima de tudo ligados aos centros capitalistas globais. Eles poderiam infundir ao PDN um "novo modo de pensar", tornando-o mais palatável, e ao mesmo tempo proporcionar uma plataforma para as ambições presidenciais de Gamal.

Mubarak, que pretendia passar o bastão para seu filho, apoiou a criação do Comitê de Diretrizes - que se tornaria o novo núcleo decisório do partido - em detrimento de seus tradicionais patriarcas. Um deles, Kamal El-Shazly, celebremente retratado no

[3] Sobre o livro, ver mais adiante. [N.T.] romance The Yacoubian Building3, teve uma morte oportuna; um outro, Safwat El-Sherif, foi relegado a um papel menos influente ao ser "promovido" a secretário-geral do partido. Consequentemente houve egos feridos com a mudança, mas nenhuma cisão séria. A velha e a jovem guarda ficaram juntas no mesmo barco, e era uma em- 
barcação formidável. O PDN tinha milhões de filiados nominais, dos quais talvez 2 milhões fossem operantes. Se um jovem empresário desejasse prosperar ou se um pequeno comerciante não quisesse ser molestado pela polícia, entrava para o partido. Assim, boa parte dessa afiliação era acomodação sem comprometimento. Mas isso não deve obscurecer o fato de que muitos têm um bocado a perder se o PDN for dissolvido.

O senhor nos fez um vívido relato sobre o triângulo do poder no qual a ditadura se apoiava. Mas é óbvio que fora do país ela contava com outro poder decisivo. Os Estados Unidos foram o avalista-mor do regime desde o momento em que Washington salvou Sadat do cerco israelense em 1973, quando as Forças de Defesa de Israel estavam prestes a interceptar as tropas egípcias no deserto do Sinai e repetir sua vitória esmagadora de 1967. O preço do resgate foi Camp David e a conversão do Egito em um pivô do sistema estratégico americano no Oriente Médio. O levante popular contra Mubarak colocou os Estados Unidos em alerta vermelho, e é razoavelmente evidente que a decisão dos militares egípcios de abandonar o presidente foi tomada sob consulta à Casa Branca, para não falar no Pentágono. Como o senhor descreveria a interface dos diversos componentes do regime com seus patronos americanos?

A partir dos anos 1980, três instituições mantiveram interações regulares com os Estados Unidos: o Serviço de Inteligência, as Forças Armadas e a presidência. Chefiado por Omar Suleiman, o Serviço de Inteligência Geral era - depois do Mossad, obviamente - o principal parceiro da CIA no Oriente Médio, trabalhando em estreita cooperação com a Agência para manipular o Exército de Libertação da Palestina, sufocar o Hamas e torturar prisioneiros no sistema de detenção americano. Após o 11 de Setembro, naturalmente, a importância do órgão para a CIA foi às alturas. Suleiman era provavelmente o oficial egípcio mais valioso aos olhos de Washington. Mubarak podia ser bronco e teimoso; Suleiman não era nem uma coisa nem outra, e tanto Israel quanto os Estados Unidos o viam como o melhor sucessor possível no governo do país.

No âmbito político do regime, a partir da época de Sadat sempre houve estreito contato entre as presidências dos dois países, com muitas visitas oficiais de parte a parte depois que o Egito se tornou um "leal aliado regional" dos Estados Unidos. Obama fez sua primeira visita ao Oriente Médio no Cairo, onde pronunciou [em junho de 2009] o discurso que rendeu seu Nobel, e poucos meses depois Mubarak estava sendo recebido em Washington. A par desse tradicional alinhamento diplomático, estreitaram-se cada vez mais os laços comerciais. Sadat afirmou explicitamente que seu melhor amigo era David Rockefeller, de quem tomou as ideias sobre como moldar a 
economia egípcia. O presidente interveio para levar ao Egito o Chase Manhattan, a Boeing, a Westinghouse, a GM e outras corporações americanas. Antes do final da década de 1980, a Câmara de Comércio Americana do Egito era o lobby de negócios mais poderoso do país. "Expedições de porta em porta" nos Estados Unidos se tornaram constantes: cada presidente que visitava o país era acompanhado por uma grande comitiva de empresários e autoridades do partido do governo, que faziam contato com diversos lobbies em Washington e circulavam pelo país depois que o presidente partia, em busca de investidores e acordos comerciais.

Essas ligações se tornaram bem mais estreitas quando Mubarak formou, em 2004, o ministério de homens de negócios encabeçado por Ahmed Nazif, o qual foi saudado com entusiasmo em Wall Street. O empresariado americano passou a se beneficiar consideravelmente com a equipe neoliberal do Cairo, ao passo que a nova elite empresarial entrincheirada no PDN esperava contar com ganhos consistentes a partir dos crescentes investimentos americanos e da mudança na política de subvenções dos Estados Unidos cogitada à época. Recursos entre 850 milhões e I bilhão de dólares que haviam sido desembolsados para o governo egípcio no passado seriam redirecionados para o setor privado, beneficiando empreendimentos notoriamente mais eficientes e menos corruptos, como todo economista sensato reconhece. Naturalmente, isso implicaria razoáveis taxas de consultoria de assessores americanos, que estariam por perto para assegurar que fossem atendidos os devidos requisitos da política de subvenções - de fato, Washington tem centenas deles no Egito atuando em seu conjunto como uma espécie de órgão ministerial paralelo. Existe portanto um forte e mutuamente proveitoso entrelaçamento de interesses entre o empresariado americano e os altos negócios egípcios, que se estende às instituições políticas dos dois países.

Quanto aos militares, nem é preciso dizer que as relações com o Pentágono têm sido extremamente estreitas. Fluxos anuais de mais de 1 bilhão de dólares para armas e treinamento - mais do que os montantes destinados a quaisquer forças armadas do mundo, exceto a de Israel - falam por si mesmos. Se isso tem trazido lealdade incondicional aos Estados Unidos, é outra questão. O Pentágono tem um interesse vital em suas relações com os militares egípcios a fim de manter controle estratégico sobre o Oriente Médio, e não há dúvida de que com frequência há fortes vínculos pessoais entre as altas patentes das duas forças. Mas isso não quer dizer que os oficiais egípcios sejam joguetes de Washington. Eles têm seus próprios pontos de vista sobre o mundo e seus devidos interesses corporativos. Após o início do levante, ficou bem claro que o recado do Pentágono 
era este: "A melhor das hipóteses é que Mubarak permaneça na presidência até setembro e então se retire honrosamente, ou - ainda melhor - que Omar Suleiman assuma o poder". Ficou igualmente claro que a certa altura os militares egípcios disseram ao pessoal da CIA que isso já não era viável: "Vocês vão ter de se conformar. Se quiserem evitar o caos, conter uma tomada de poder islâmica, impedir qualquer desestabilização que possa afetar Israel, precisamos dar um empurrãozinho para que o presidente saia do poder". Os Estados Unidos acabaram aquiescendo. Embora os militares certamente tenham consultado Washington, creio que tomaram uma decisão sensata por seus próprios motivos.

\section{O MÊS SEGUINTE}

O Conselho Militar Supremo foi o órgão que tomou essa decisão ao se reunir em 10 de fevereiro. Qual é o status dele, quem o compõe e como ele opera?

Teoricamente, o Conselho se reúne quando o país está em guerra. Assim foi em 1967 e em 1973, em ambas as ocasiões sob a direção do presidente na qualidade de comandante em chefe das Forças Armadas - ou seja, Nasser na primeira e Sadat na segunda. Desse modo, quando o Conselho se reuniu em 10 de fevereiro sem a presença de Mubarak e um analista militar explicou na televisão que o órgão se reunira por iniciativa própria, sem uma convocação do comandante em chefe, foi o equivalente a um motim, anunciando que o regime de Mubarak terminara.

Desde então o Conselho está em sessão permanente, reunindo-se no Ministério da Defesa. Ele é composto pelo ministro da Defesa, pelo chefe do Estado-Maior, pelos comandantes das cinco forças, pelos chefes dos cinco distritos militares em que o país é dividido e pelos chefes dos departamentos especializados: de Inteligência, de Assuntos Legais, e assim por diante. Até onde sabemos, as decisões são tomadas coletivamente, por consenso. Até o momento, o Conselho tem tido o cuidado de alternar os membros que falam pelo órgão para evitar a impressão de que uns poucos predominam.

O presidente do Conselho, o ministro da Defesa Tantawi, era um colaborador de Mubarak de longa data - não faz muito tempo, ele foi zombeteiramente referido como seu "poodle" por oficiais egípcios de patente intermediária, segundo despachos americanos revelados pelo Wikileaks. Como o senhor avalia o papel dele no momento?

Tantawi era o comandante da Guarda Republicana antes de se tornar ministro da Defesa. Como ministro, ele tinha duas credenciais: uma da corporação militar e a outra do aparato político em torno 
[4] Estância balneária com instalações turísticas suntuosas, localizada junto ao mar Vermelho no extremo sul da Península do Sinai. [N.T.]

[5] Título da tradução inglesa da obra do escritor egípcio, publicada originalmente em árabe em 2002 com o título Imarat Yaqubian (A residência Yacoubian). [N.T.] da presidência, ainda que desde os tempos de Sadat o ministro da Defesa não possa ser membro do PDN formalmente. Ele por certo era muito ligado a Mubarak, mas compreendeu que este tinha de ser abandonado, e então resolveu pôr de lado suas credenciais políticas e acompanhar os demais militares. Isso posto, Tantawi está envelhecido (tem 75 anos) e não se sabe bem quanta autoridade ele exerce no Conselho Militar Supremo.

Seria correto dizer que o evento mais impactante desde a queda de $\mathrm{Mu}$ barak foi o afastamento do primeiro-ministro Ahmed Shafiq, outro colaborador próximo, a quem ele incumbiu de esmagar o levante e cuja demissão o Conselho Militar Supremo foi obrigado a aceitar - certamente não foi iniciativa do órgão - em 3 de março?

Shafiq era um general da Aeronáutica que declarava orgulhosamente que Mubarak o ensinara a voar, além de várias outras capacitações. Mubarak o tornou comandante da Aeronáutica, e eles sempre foram amigos íntimos - muita gente diz até que são parentes por afinidade. Depois da aposentadoria dele, Mubarak o nomeou ministro da Aviação Civil num momento em que a pasta estava por desfrutar de enormes vantagens, como um aeroporto internacional novo e de grande porte, renovação da companhia aérea nacional, e assim por diante. Portanto, ele era um político civil que adornava o partido do governo fazia quase uma década quando foi nomeado primeiro-ministro. Seu desempenho desde a revolta foi desprezível. Ele ridicularizava os manifestantes, dizendo que a praça Tahrir era uma Hyde Park Corner fajuta e que as pessoas reunidas ali deveriam receber doces e chocolates. Em vez disso, o que houve ali foi a brutal investida dos capangas da polícia em 2 de fevereiro. Sua promessa de pronta justiça não deu em nada, e ele insultava repórteres que lhe faziam perguntas incômodas. Depois de declarar expressamente que Mubarak jamais renunciaria, ele saudou a "grandiosa revolução" de 25 de janeiro. Nesse ínterim, foi amplamente noticiado que Shafiq ainda entrava em contato com Mubarak no luxuoso refúgio dele em Sharm el-Sheikh4.

No dia 2 de março, Shafiq apareceu como primeiro-ministro num talk show televisivo junto com Naguib Sawiris, milionário das telecomunicações copta e pródigo mecenas (uma espécie de George Soros egípcio), o popular apresentador de TV Hamdi Kandil (nenhum parentesco) e o romancista Alaa Al-Aswany, autor de The Yacoubian Buildings. Lá estava ele sendo publicamente chamado às falas pela investida na praça de 2 de fevereiro e por não ter responsabilizado quem quer que fosse pelo saldo de mortos e feridos nas mãos da polícia durante a revolta (estimado pelos noticiários mais recentes em 685 mortos e mais de 5 mil feridos). Al-Aswany perguntou a ele 
como é que Mahmoud Wagdy, seu novo ministro do Interior - nomeado durante a revolta e reconduzido ao cargo por Shafiq após a saída de Mubarak - , podia continuar alegando que francoatiradores estrangeiros teriam matado as pessoas e que a polícia havia feito um trabalho excelente. Perdendo as estribeiras, Shafiq gritou em resposta: "Não vista o véu do patriotismo ao falar comigo!". Kandil indagou-lhe sem rodeios se ele não tinha vergonha de permanecer em seu posto, visto que estava totalmente evidente que o povo o rejeitava. No dia seguinte a esse bate-boca diante de toda a nação ele estava fora do governo.

Esse notável episódio levanta a questão mais ampla do papel das diversas mídias - a televisão, a imprensa, o rádio e as redes sociais da internet - antes, ao longo e depois do levante. O senhor poderia dizer algo sobre isso?

Durante quarenta anos, todos os meios de comunicação foram controlados pelo Estado sob aquilo que Nasser originalmente denominou Ministério da Orientação Nacional e depois Sadat chamou de Ministério da Informação. Mas nos anos 1990, em meio à convicção à qual me referi de que não restara nenhuma oposição séria, Mubarak permitiu o surgimento de mídias independentes que criticavam abertamente o presidente, sua família e a situação do país - alguns jornais e canais de TV e um cinema independente bastante dinâmico. Havia apenas algumas linhas vermelhas que não podiam ser ultrapassadas. Estrangeiros frequentemente se surpreendem com o fato de que um filme como The Yacoubian Building ${ }^{6}$ possa ter sido feito no Egito, mas foram lançados vários outros filmes não menos críticos em relação ao regime, alguns deles ainda mais críticos. Como tudo isso foi possível? Em boa medida, porque a visão do regime era de que na ausência de qualquer oposição organizada aquilo tudo não passaria de conversa mole. Poderia até mesmo ser útil como uma válvula de escape: se fosse permitido às pessoas desabafar de vez em quando, o sistema poderia sair ganhando com isso. Mas a história também foi um fator importante. Os primeiros filmes egípcios surgiram já nos anos 1920. A televisão egípcia, inaugurada em 1960, foi a primeira a aparecer no mundo árabe. Havia uma longa tradição cultural no país, não comparável com nada no Golfo, por exemplo. Assim, era complicado reprimir a televisão e a internet. O regime decidiu que era mais prudente permitir a expressão dentro de certos limites negociados.

Politicamente, os talk shows se tornaram o formato mais importante no novo cenário: vão ao ar à noite em emissoras de TV aberta independentes, têm âncoras de grande prestígio e duram de duas a três horas, às vezes até mais, abordando e discutindo
[6] Título da versão inglesa do filme Imarat Yaqubian (Egito, 2006), dirigido por Marwan Hamed a partir de roteiro adaptado do livro supracitado. [N.T.] 
tudo o que aconteceu durante o dia. Há quatro ou cinco programas desse tipo, aos quais os egípcios se mantêm grudados toda noite para ter uma noção geral sobre a situação do país. No apagar das luzes, é claro, o regime começou a cercear alguns desses programas de uma forma ou de outra, mas eles nunca foram completamente interditados, com o que desempenharam um papel fundamental durante a revolta e continuaram a fazê-lo posteriormente. Fora do país, generalizou-se a impressão de que o Facebook foi o principal meio de comunicação no levante, e por certo ele foi crucial para a geração mais jovem nos primeiros dias dos protestos, mas os talk shows eram bem mais acessíveis para os egípcios em geral. No transcurso do levante, esses programas entrevistavam manifestantes, policiais, repórteres, homens de negócios, operando como um fórum de discussão amplo e muito eficaz.

Depois que Mubarak foi deposto, os militares acabaram por ceder às reivindicações populares e o Ministério da Informação foi extinto. Da noite para o dia, os meios de comunicação estatais mudaram seu discurso com açodamento risível, passando a denunciar o ex-presidente e sua família e a tecer loas ao movimento que o derrubara. Mas eles não têm credibilidade alguma. São os talk shows independentes que detêm a atenção pública. Os organizadores dos movimentos jovens foram recebidos neles; membros da comissão encarregada de emendar a Constituição apresentaram seu trabalho neles; representantes do Conselho Militar Supremo compareceram num programa com quatro horas de duração para responder perguntas dos telespectadores sobre o que estavam fazendo; líderes da Irmandade Muçulmana e de outros grupos oposicionistas também se apresentaram - em suma, todos os atores do drama político em curso se fizeram ali presentes. As pessoas assistem a esses programas não só porque assim podem sentir o pulso do que está ocorrendo no país, mas também porque eles acabam se tornando eventos políticos em si mesmos, como no episódio de Shafiq.

\section{E o ministério que substituiu o de Shafiq? Que caráter tem ele?}

O novo primeiro-ministro, Essam Sharaf, é engenheiro e catedrático da Universidade do Cairo. Ele foi nomeado ministro dos Transportes na gestão Nazif em 2004, mas em pouco tempo renunciou depois de alguns conflitos com ela. Durante a revolta ele foi à praça e declarou solidariedade para com seus ocupantes, motivo pelo qual foi um dos nomes propostos pelos manifestantes ao Conselho Militar Supremo para chefiar o governo. Entre os três ministérios mais importantes, a pasta das Relações Exteriores ficou com Nabil El-Araby, um diplomata que acompanhou Sadat em Camp David e divergiu do acordo dele com Begin para depois seguir carreira nas Nações Unidas, em 
várias comissões e no Tribunal Internacional de Justiça. O ministro do Interior, Mansour Al-Essawi, é um oficial de polícia de uma das áreas mais ao sul do Sa'id, conhecido por seus esforços para combater a corrupção; residia em Paris de tempos em tempos, alheio ao regime. Ele já dissolveu o Serviço de Segurança do Estado. O ministro da Justiça, Mohamed El-Guindy, foi procurador-geral da Justiça e é um magistrado com visão independente. O Ministério da Justiça é crucial do ponto de vista político, já que é responsável pela supervisão eleitoral. Duas outras figuras significativas são Samir Radwan, ministro das Finanças, e Gouda Abdel-Khaleq, ministro da Justiça Social. Ambos são professores de economia com nítidas tendências esquerdistas - Abdel-Khaleq é até membro do Tagammu, o Partido Comunista autorizado.

Então eles pertencem à tradição comunista que colaborava com Mubarak? Quando os Oficiais Livres tomaram o poder em 1952, havia três organizações comunistas no Egito: o Partido Comunista Egípcio, o Partido da Vanguarda dos Trabalhadores e o Movimento Democrático pela Libertação Nacional. Este último aderiu a Nasser desde o início, mas os outros dois não, e foram reprimidos por ele. Posteriormente, nos anos 1960, ele soltou seus membros da prisão sob a condição de que todo o movimento comunista se dissolvesse e integrasse a União Socialista Árabe. Seu intento era cooptar a elite intelectual comunista, usando-a em posições oficiais para seus propósitos, e livrar-se integralmente dos militantes comuns. Essa situação perdurou até o final dos anos 1970, quando Sadat pediu a Khaled Mohieddin - um veterano dos Oficiais Livres que sempre fora próximo dos comunistas e havia sido expurgado por Nasser em 1954 - que montasse um partido que reunisse o que restava daquela tradição para oferecer uma mínima e leal oposição ao PDN. Então Mohieddin formou o Tagammu como um abrigo respeitável para os intelectuais de esquerda daquela procedência. Em 2003 Mohieddin foi sucedido na liderança do partido por Refaat El-Saeed, que fez um acordo com Mubarak sob o pretexto de que o islamismo era o inimigo comum de ambos. Assim, ao longo dos anos 1990 e na primeira década deste século, o comunismo egípcio ficou completamente alinhado com o governo. Mas o que restou dele ainda contém intelectuais com alguma competência profissional, dos quais os dois que ora detêm postos ministeriais são bons exemplos.

Por que as execradas leis de emergência ainda não foram suspensas, agora que Mubarak se foi?

Os militares prometem que elas serão ab-rogadas uma vez que forem empossados um novo presidente e um novo parlamento. Não 
obstante, a verdade é que essas leis estão em vigor quase ininterruptamente desde 1948. Em certo sentido elas são uma formalidade antes o símbolo de um estado de coisas que uma circunstância em si. O verdadeiro problema é a cultura da polícia: a lei, seja de emergência ou não, não existe para os policiais. Eles acabaram por presumir que podem fazer tudo o que querem: grampear telefones, revistar residências, prender pessoas, espancá-las. Quando as leis de emergência forem ab-rogadas, no dia seguinte ainda poderá haver um oficial de polícia que está nas ruas há vinte anos e não entende por que precisa de um mandado judicial para grampear o telefone de alguém que ele suspeita estar traficando drogas, ou por que um suspeito que se recusa a falar não pode ser estapeado e eletrocutado. Ele faz essas coisas porque é o único jeito de proceder que ele conhece.

A indignação popular com essa opressão cotidiana é muito forte. Um incidente ocorrido há poucas semanas em Maadi, uma área de classe alta do Cairo, pode dar uma ideia das tensões que isso gera. Um jovem oficial de polícia teve uma discussão de trânsito com um motorista de ônibus. No auge da irritação, sacou sua arma e atirou no braço do cidadão. Em vez de virar as costas, algumas pessoas que testemunharam a cena ficaram tão enfurecidas que o atacaram e o espancaram quase até a morte. Esse tipo de coisa é muito provável de acontecer enquanto persistir essa cultura da violência policial arbitrária. As leis de emergência precisam ser abolidas, mas é sobretudo o fortalecimento dos direitos dos cidadãos que poderá mudar isso.

Na Tunísia, o partido que estava no poder, o Neo-Destour, foi declarado ilegal. Em alguns aspectos, a ditadura de Ben Ali era ainda mais repressora do que a de Mubarak, mas como partido do governo o PDN era muito parecido com o Neo-Destour. Quais são as perspectivas dele agora?

Enquanto não houver nenhuma mudança radical no cenário socioeconômico, proscrever o partido ainda é em grande medida um ato simbólico, já que as forças ali acomodadas vão acabar se reagrupando num outro organismo. É verdade, porém, que se seus líderes fossem proibidos de disputar a próxima eleição, mas autorizados a se reagrupar daqui a quatro anos ou algo assim, seria de esperar que no fim das contas o partido se tornasse uma organização mais inteiramente reformulada. Mas com toda probabilidade ele reteria uma força eleitoral considerável, preservando suas vigorosas redes clientelísticas, e continuaria em posse de um grande cacife econômico e político.

E se ele fosse destituído de seus bens?

O PDN não detém muitos bens diretamente em seu nome. O que ele efetivamente possui são duas bases importantes. Uma delas é cons- 
tituída pelo seu domínio na burocracia governamental, um quadro de 6 milhões de pessoas cujas dotações propiciavam um fluxo constante para os cofres do partido e cujos serviços, respaldos e votos sempre estiveram à sua pronta disposição. Isso o PDN irá perder. Sua outra base não minguará tão facilmente, já que compreende homens de negócios e proprietários de terras abastados que usavam seus patrimônios particulares tanto para apoiar o partido como para se beneficiar dele, tratando de garantir retornos para seus investimentos. Salvo confiscos de seus bens, eles terão os recursos necessários para voltar a operar. A questão crucial será a perda da burocracia. Resta saber até que ponto isso irá ocorrer. O PDN tem uma porção de redes informais amadurecidas ao longo do tempo. Em que medida elas poderão ser desfeitas?

Quando se convocarem eleições, o partido deverá ter um bom desempenho? Se lhe for permitido disputar a eleição parlamentar deste ano, certamente terá. Otimistas estimam que o PDN possa ficar com um terço das cadeiras, ao passo que a Irmandade Muçulmana também ficaria com um terço e os demais partidos ocupariam um terço restante. Uma visão mais pessimista é a de que o PDN e a Irmandade Muçulmana dividiriam $80 \%$ do eleitorado entre si. Mesmo na visão mais otimista, se o PDN fosse proscrito, pessoas candidatando-se de forma independente mas na verdade representando a velha ordem provavelmente comporiam um terço do parlamento ou mais. As forças que efetivamente derrubaram a ditadura vão constituir uma minoria na Assembleia.

Qualquer que seja a forma que a Constituição assuma, parece que o presidente terá poderes muito amplos. É possiviel fazer alguma suposição sobre quem deverá subir ao posto?

Certamente não será ninguém muito obviamente ligado ao partido que estava no poder. Até o momento surgiram poucos candidatos. Um deles é Amr Moussa, secretário-geral da Liga Árabe, um tanto marginalizado pelo regime nos anos recentes, mas ministro das Relações Exteriores de Mubarak por uma década. Outro concorrente de destaque é El-Baradei, bem menos associado com a ditadura. Também está na parada o alto magistrado Hisham Al-Bastaweissy, incansável crítico do regime e um tradicional defensor da independência do Judiciário. Alguns falam em Mohamed Mahgoub, um coronel da inteligência militar reputado como um ótimo governador de Alexandria, onde se tornou tão popular que foi nomeado titular do desimportante Ministério do Desenvolvimento Local. Desse modo, ele não é visto como alguém procedente do alto escalão do governo. A Irmandade Muçulmana afirmou que não irá lançar candidato, mas quem quer que venha a apoiar terá uma sólida margem de votos. 
[7] Sigla em turco do Partido da Justiça e do Desenvolvimento, fundado em 2001. [N.T.]
Que rumo político a Irmandade Muçulmana poderá tomar, agora que está legalizada?

Estamos num momento em que todos os atores principais estão se redefinindo, numa situação completamente nova. Há várias razões para que a Irmandade se mostre mais enfraquecida. A maior parte de sua força derivava do fato de que ela levantava a bandeira da oposição ao regime autoritário e muitos de seus militantes eram torturados ou morriam na prisão, mas já não há necessidade de mártires, mesmo que tenhamos uma forma de democracia restrita. A outra grande força da organização residia em seus serviços de bem-estar, os quais, em meio a um sistema corrupto que pouco ou nada concedia aos pobres, proporcionavam efetiva assistência e solidariedade material. Mas esse cabedal também irá diminuir se houver, pela primeira vez, um governo que dê atenção às necessidades da população carente.

Há que se considerar ainda o conflito entre a velha e a jovem guarda no interior da Irmandade, que vem de longo tempo. Os membros da velha guarda são pessoas que passaram a maior parte da vida na prisão. Seu principal argumento para deter a supremacia é que eles sabem como operar nas sombras e sustentar um movimento clandestino, enquanto os reformistas jovens e idealistas não sabem. Na medida em que já não há perigo mortal e a atuação política passa a se dar às claras, porém, esse argumento recorrente fica sem efeito. A Irmandade Muçulmana pode emergir como um ator importante, mas não tal qual a organização que conhecemos até agora. Ela teria de se tornar outro tipo de agremiação, com uma identidade islâmica mais genérica, talvez como o AKP7 da Turquia.

E quanto à Coalizão da Juventude da Revolução de 25 de Janeiro e às diversas forças que emanaram do levante?

Era uma frente heterogênea, e ainda não há nenhum sinal de que ela seja capaz de se consolidar num partido político unificado. Se isso ocorresse, seu principal componente seria liberal. Mas esses liberais achariam problemático atuar com esquerdistas e islamitas. Assim, o mais provável é que haja um organismo majoritariamente liberal com grupos esquerdistas e islâmico-reformistas de menor porte ao lado dele. É nesse sentido que os desdobramentos parecem apontar neste momento, para uma dispersão do potencial do movimento. A esperança de que essas forças pudessem superar suas diferenças para formar um único partido verdadeiramente radical parece irrealista. Elas divergem em inúmeras questões básicas. Atuando em cooperação, talvez consigam obter um terço dos votos, mas esta é a melhor das hipóteses. 
Quem são os liberais no Egito de hoje e qual é a visão deles?

Aqueles agrupados em torno de El-Baradei e do partido ao qual ele é mais estreitamente associado, a Frente Democrática, podem ser apropriadamente descritos como liberais, assim como aqueles que orquestraram as convocações no Facebook no início do levante. Pode-se ainda mencionar os apoiadores de Ayman Nour e do partido El-Ghad [do Amanhã], que ele criou antes de ir para a prisão. Muitos dos representantes desse campo de ideias provêm do histórico Wafd, o partido do nacionalismo liberal sob a monarquia, que parece estar ressurgindo. Na mídia e na intelectualidade - praticamente na cultura em geral - , há hoje em dia uma grande nostalgia da época em que o Wafd era a principal força política no país. Nos últimos cinco ou seis anos vem-se nutrindo uma espécie de fixação no Egito dos anos 1920 aos anos 1940; trata-se de uma idealização desse período na forma de uma utopia liberal que se generalizou em romances e filmes. Al-Aswany é um ótimo exemplo. Uma das projeções usufruídas pelos islamitas residia na imagem cativante do Profeta e de sua vida em Medina - mais uma fonte de utopia. Agora é a idade de ouro dos anos 1920 que vem arrebatando o imaginário egípcio. Todos os candidatos presidenciais estão evocando essa imagem de um passado melhor, mais aberto e cosmopolita.

\section{PERSPECTIVAS}

Como se poderia avaliar o plebiscito sobre as emendas constitucionais?

O Conselho Militar Supremo criou uma comissão para propor emendas à Constituição, encabeçada por um jurista e historiador com inclinações islâmicas, Tareq El-Bishri, e contendo um membro da Irmandade Muçulmana. A escolha de El-Bishri é bastante significativa. Não só porque ele é geralmente considerado um dos mais importantes intelectuais do Egito, mas sobretudo porque seu principal estudo histórico, que examina a vida política egípcia entre o fim da Segunda Guerra Mundial e o golpe que ocorreu sete anos depois, é emoldurado pela seguinte questão: por que a vibrante mobilização política nas ruas entre o fim dos anos 1940 e o início dos anos 1950, fértil como era de alternativas e movimentos revolucionários, não acabou gerando uma tomada do poder nesse sentido, permitindo que os militares interviessem? Em outras palavras, uma das preocupações primordiais de El-Bishri é compreender como os militares subiram na crista dos protestos radicais de 1952 e usurparam a revolução. Todas as entrevistas que ele vem concedendo desde sua nomeação pelo Conselho Militar Supremo têm refletido sua determinação de não deixar que isso volte a acontecer. 
A comissão propôs uma série de alterações que eliminam restrições da ditadura aos candidatos à presidência, reduzem o mandato presidencial de cinco para quatro anos, permitindo um máximo de duas gestões, e limitam a prerrogativa do presidente de declarar estado de emergência a um período de seis meses, somente renovável por aprovação plebiscitária. Por insistência dos militares, esse pacote de propostas foi submetido a votação como que de supetão, no dia 19 de março. Os membros do PDN ainda ativos e os islamitas, capitaneados pela Irmandade Muçulmana e pelos salafitas (muçulmanos puritanos), defenderam a aprovação do pacote. A Coalizão da Juventude, El-Baradei e outros candidatos à presidência, bem como forças liberais e esquerdistas, se opuseram a ele, perguntando por que se deveria emendar a Constituição fabricada pela ditadura em vez de se deliberar democraticamente sobre uma nova Carta. O pacote proposto requer uma assembleia constituinte a ser nomeada por um parlamento também eleito às pressas - neste outono [entre setembro e novembro] - para redigir uma nova Constituição. Aqueles que apoiaram o procedimento do plebiscito argumentavam que ele minimizaria o perigo de que os militares se entrincheirassem no poder (seguindo a lógica da preocupação de El-Bishri). Os que o rejeitavam argumentavam que a correria para realizar um plebiscito de escopo tão restrito era calculada para assegurar que as duas organizações constituídas há mais tempo, o PDN e a Irmandade Muçulmana - cada qual à sua maneira totalmente conservadora, e as menos propensas a contrariar o Alto Comando - , predominassem no contexto pós-regime.

O comparecimento às urnas no plebiscito foi de $41 \%$ do eleitorado. Por quais parâmetros isso pode ser avaliado?

Para os padrões egípcios, é um número razoavelmente alto. A população do país está próxima de 85 milhões de habitantes, dos quais 45 milhões têm direito a votar, e entre estes 18 milhões o fizeram. Parece um comparecimento pequeno quando comparado aos dados oficiais sobre várias votações plebiscitárias e eleitorais realizadas sob o velho regime, mas esses números eram sempre fraudulentos. Era fácil perceber isso porque na realidade nunca víamos pessoas votando em número significativo. Dessa vez foi completamente diferente. No Cairo, havia longas filas em cada local de votação desde a manhã até a noite. Como era de esperar, o comparecimento foi alto nas grandes cidades e bem mais baixo no campo. Teoricamente, cerca de $60 \%$ da população ainda é classificada como rural, mas na prática a maioria das pessoas mora em vilarejos do tamanho de pequenas cidades. Hoje em dia, o campesinato propriamente dito corresponde a apenas um quarto da 
força de trabalho. Não há problemas de inscrição eleitoral, já que agora todo mundo recebe um documento de identidade magnético. Ademais, o comparecimento provavelmente será bem maior nas eleições parlamentares.

Como se deve interpretar a acachapante votação a favor das emendas constitucionais, aprovadas por $77 \%$ dos eleitores?

Isso está sendo muito discutido agora. O que parece claro é que o voto no "sim" significou coisas diferentes para pessoas diferentes. Muitos votaram a favor das emendas sob a crença de que sua aprovação era necessária para que o país voltasse a funcionar. Essa provavelmente foi a razão predominante da dimensão do voto no "sim" - o receio de que o voto no "não" prolongaria a incerteza e o caos, evitando o retorno à normalidade. Podia-se frequentemente ouvir pessoas dizendo que iam votar no "sim" porque queriam voltar a trabalhare ver a economia começar a se restabelecer. Era muito difícil para elas compreender que isso não tinha nada a ver com votar no "sim" ou no "não". Outro fator importante foi a crença, igualmente equivocada, de que o voto no "sim" era necessário para preservar o artigo n. 2 da Constituição, que declara os princípios da xariá ${ }^{8}$ como a base da legislação - de que o voto no "não" significaria a revogação da Constituição existente. $\mathrm{Na}$ verdade, haverá uma nova Constituição de qualquer jeito, independentemente do resultado do plebiscito. As pessoas comuns votaram no "sim" essencialmente por essas razões. Elas estavam enganadas, mas isso é compreensível. Por certo, três atores organizados as influenciaram: os remanescentes do PDN, os membros da Irmandade Muçulmana e os fundamentalistas salafitas - os dois últimos atuando particularmente no tocante àquele segundo receio.

\section{De quando data o artigo n. 2 da Constituição?}

Embora poucas pessoas tenham ciência disso, sua história remonta à primeira Constituição egípcia, promulgada em 1923, na qual um artigo determinava que a xariá fosse uma das principais fontes da legislação. Havia um artigo similar na Constituição de 1954, elaborada depois que os Oficiais Livres chegaram ao poder, e ele foi reintroduzido nas Cartas de 1964 e 1971. Em 1980, Sadat propôs duas emendas constitucionais: a primeira elevava a condição da xariá como apenas uma das principais fontes da legislação para à de principal fonte, e a segunda facultava ao presidente ser reeleito indefinidamente - o real objetivo de Sadat. A primeira emenda foi concebida como uma cobertura para a segunda em um pacote fechado a ser submetido a referendo. Com a aprovação das medidas, Sadat formou uma comissão que deveria assegurar que todas as leis estivessem de acordo com
[8] Código de leis do islamismo (mais comumente grafado conforme a transliteração do árabe para o inglês: "sharia" ou "shariah"). [N.T.] 
a xariá. A comissão se reuniu ao longo de cinco meses sem chegar a conclusão alguma, e nunca mais se ouviu falar dela.

O voto "não" ficou concentrado na província do Cairo, onde alcançou $39,48 \%$, e em menor proporção nas de Alexandria e Giza, com $32,87 \%$ e $31,82 \%$ respectivamente. Como se poderia avaliar esses resultados?

Levando em consideração o forte anseio por uma volta à normalidade e os vínculos com a religião no discernimento popular, a magnitude do voto "não" no Cairo - correspondente a quase dois quintos dos que votaram - foi impressionante. A campanha pela rejeição do pacote de emendas foi conduzida pelos liberais e esquerdistas que estiveram na linha de frente do levante. Quanto à organização política, esses grupos ainda são bem pequenos. O que o voto "não" no Cairo - do qual Giza é praticamente uma extensão - e em Alexandria mostrou foi a considerável base social de que essas forças potencialmente poderiam dispor num Egito democrático, sobretudo na classe média intelectualizada mas também entre os trabalhadores urbanos. O fato de que tantos eleitores tenham seguido sua orientação num plebiscito realizado tão às pressas, e em meio a tanta confusão acerca de seu propósito, assinala a autoridade política que elas adquiriram ao liderar o levante. No entanto, se esse papel de vanguarda ainda em potencial não assumir uma forma organizacional em breve, é provável que a memória da praça Tahrir se desvaneça. Até o momento há pouquíssimos sinais de tal organização. Os ativistas não islâmicos ainda estão em boa parte se ocupando com os mesmos debates casuísticos que os absorviam antes da revolta. Muito embora a virtual suspensão da censura lhes propicie um espaço de expressão pública ampliado, eles parecem continuar discutindo e rediscutindo minúcias como se nada tivesse mudado.

Duas outras zonas eleitorais, neste caso não metropolitanas, registraram votos no "não" bem acima da média nacional: as das províncias do mar Vermelho e do Sinai do Sul, com 36,62\% e 33,06\%. O que explica esses resultados?

Provavelmente o medo do islamismo. Essas são regiões em que a subsistência da população depende do turismo, e as pessoas receiam que as atividades turísticas possam ser prejudicadas se forem impostas restrições a bebidas alcoólicas ou a roupas de banho. Ao ver o lado para o qual os grupos religiosos estão indo, elas tendem a votar na direção oposta.

Quais serão os efetivos desdobramentos do plebiscito?

A posição oficial das Forças Armadas é a de que elas não querem que uma nova Constituição seja promulgada sob o domínio mi- 
litar, mas num contexto democrático. Assim, a agenda posterior ao plebiscito deve ser mais ou menos a seguinte. Primeiro haverá eleições parlamentares, provavelmente em setembro, seguidas de eleições presidenciais em dezembro ou início de janeiro. $O$ parlamento será solicitado a nomear num prazo de seis meses uma assembleia constituinte, a qual terá outros seis meses para elaborar uma Constituição. Uma vez redigida, essa nova Constituição será submetida a um referendo num prazo de quinze dias. Aqueles que fizeram campanha pelo voto "não" no plebiscito argumentavam que nesse cenário o parlamento tenderia a ser controlado por remanescentes do PDN e por membros da Irmandade Muçulmana, com o que a assembleia constituinte iria refletir esse predomínio. A réplica dos militares era a de que uma constituinte eleita de imediato provavelmente teria o mesmo equilíbrio de forças de um parlamento eleito em setembro, de modo que não caberia nenhuma objeção a este último.

\section{A Coalizão da Juventude reivindicou formalmente a dissolução do parti-} do que estava no poder. Alguém mais se posicionou nesse sentido?

Sim, esta é uma grande questão no momento. Mas ainda não está claro qual será o destino do PDN. Até agora, a linha de ação do Conselho Militar Supremo tem assumido o seguinte padrão: de início ele não reage às reivindicações populares e em seguida, de modo súbito, atua de acordo com elas. Assim foi nos casos da destituição da gestão Shafiq e da extinção do Ministério da Informação e do Serviço de Segurança do Estado. Vamos ter de esperar para ver`. Sem dúvida, há uma expectativa bastante generalizada de que pelo menos os membros da liderança do partido sejam excluídos das próximas eleições. Os militares afirmam que em breve anunciarão as regras para a formação de partidos e para a realização das eleições.

\section{Como evoluiu a situação dos meios de comunicação desde a derrubada de Mubarak?}

Esta é outra questão fundamental. A par da demanda pela dissolução ou por uma neutralização do partido do regime deposto, reivindicou-se amplamente um expurgo dos agentes que comandam os meios de comunicação estatais. Isso não só porque a população ficou irritada com o ridículo espetáculo de notórios arautos da ditadura se apresentando de uma hora para outra como defensores da revolução, mas também porque a mídia estatal se pôs a fazer um jogo duplo, alardeando todo tipo de ameaças às grandes conquistas da revolução na tentativa de criar um estado de pânico que favoreceria uma restauração da velha ordem. Após manifestações que exigiram veementemente o afastamento dos dirigentes de
[9] Em 16 de abril de 2011, por determinação judicial, o PDN foi dissolvido e teve seus bens confiscados. [N.T.] 
emissoras de TV e de jornais controlados pelo Estado, no dia 2 de abril o primeiro-ministro assinou dois decretos expurgando quase uma dúzia deles.

\section{Como se afigura a situação no âmbito sindical?}

De modo bastante contraditório. Ainda há bem pouca pressão vinda das bases. A maior parte dos trabalhadores ainda está essencialmente preocupada com suas necessidades cotidianas - remuneração, férias, condições de trabalho - , apresentando pouquíssimas reivindicações políticas abrangentes. Por outro lado, há certa politização vinda do topo. O novo ministro do Trabalho, Ahmed Hassan El-Borai - um jurista especializado em relações trabalhistas que há muito tempo é sensível às causas dos trabalhadores e é muito respeitado por eles - , promete que num prazo de seis meses haverá uma nova regulamentação trabalhista, com garantia de salário mínimo e do direito de organizar sindicatos independentes e uma confederação dos trabalhadores. Ao mesmo tempo, porém, o novo governo fez um anteprojeto de lei que criminaliza greves, protestos, manifestações e ocupações que interrompam atividades privadas ou serviços estatais ou afetem a economia, enquanto as leis de emergência estiverem em vigor. Naturalmente, essa tentativa de repressão está deparando com intensa oposição de sindicados independentes, para não falar dos segmentos esquerdistas e liberais de modo geral.

O que aconteceu nesse interim em meio aos grupos liberais e esquerdistas que propulsionaram o levante? Ocenário ainda é praticamente o mesmo ou se alterou?

Infelizmente, pouca coisa mudou. Duas grandes questões dividem esse campo de posições. Uma é a da organização: os diversos grupos que lideraram o levante deveriam manter suas identidades, reagrupar-se por trás de uma das forças já existentes ou constituir alguma nova associação? Houve negociações para saber se a Frente Democrática - um dos vários partidos liberais formados nos últimos anos de Mubarak - poderia ser remodelada para reunir várias tendências, mas os membros mais velhos da agremiação resistiram àquilo que viram como uma tentativa dos mais jovens de usurpá-la. Outros insistiram na necessidade de instituir um novo partido, mas isso ainda não se concretizou, em parte por causa das diferenças em torno da posição que ele deveria tomar acerca da religião.

Esta é a outra grande questão que agora, na esteira do plebiscito, está diante do campo do "não". Há muito tempo os intelectuais liberais e esquerdistas vêm defendendo uma completa secularização da cultura egípcia, buscando convencer as pessoas a relegar a religião 
à esfera privada, ou ao menos a deixá-la de lado quando se trata de tomar decisões políticas. Desde a revolta, muitos passaram a achar que agora possuem autoridade moral para insistir nisso. No entanto, o plebiscito mostrou os riscos dessa posição. Ela contraria muitas pessoas comuns que rejeitam a secularização do Estado de maneira categórica, e se essa demanda for colocada em primeiro plano elas instintivamente irão se fechar e não darão ouvidos a nada mais que se apresente a elas. Desse modo, outros argumentam que qualquer programa político realista deve reconhecer claramente que o lugar do Islã no Egito tem de continuar a ser respeitado. Tanto no aspecto organizacional como no religioso, a frente liberal-esquerdista ainda está um tanto desencontrada.

\section{Como se posicionam as várias forças islâmicas?}

Esta é uma história complicada. Grosso modo, há três segmentos principais. A Irmandade Muçulmana, que é o segmento mais antigo e mais numeroso, parece estar indo de vento em popa após sua participação na vitória do "sim" no plebiscito. Mas também corre o risco de se fragmentar à medida que ingressa na arena político-partidária. O partido Al-Wasat [O Centro], que surgiu de uma dissidência com a Irmandade Muçulmana há mais de dez anos (embora só tenha sido oficializado recentemente), vem atraindo muita gente da Irmandade como uma alternativa islâmica mais moderada. Quando houve a revolta, o partido tinha apenas cerca de setenta membros. Nas primeiras semanas de março, ganhou a adesão de 30 mil pessoas desiludidas com a Irmandade, na sua maioria gente jovem. Ao mesmo tempo, a juventude ligada à ala reformista da Irmandade está ameaçando criar um partido próprio - o Nahda, ou Partido do Renascimento - a menos que todos os atuais dirigentes da Irmandade renunciem a seus postos para que haja eleições democráticas e transparentes dentro da organização, com o acompanhamento de observadores independentes.

Um segundo segmento é composto de fundamentalistas combatentes, ou salafitas políticos. Nele havia dois grandes grupos, Al-Gama'a al-Islamiyya [O Grupo Islâmico] e Al-Jihad [A Luta], além de várias facções menores. Esses grupos escolheram o caminho da luta armada contra a ditadura porque não viam nenhuma perspectiva de mudança pacífica. Foi uma unidade da Jihad que eliminou Sadat. Na repressão que se seguiu a seu assassinato, os líderes originais da Jihad foram perseguidos e presos. Os militantes que escaparam, em especial Ayman Al-Zawahiri, decidiram que o regime, apoiado pelo Ocidente, era forte demais para ser enfrentado, e então redirecionaram sua campanha do "inimigo próximo" (o regime autoritário) para o "inimigo distante" (os 
aliados ocidentais do regime) por via de organizações combatentes globais, como a Al-Qaeda. Grupos dissidentes, cuja força era baseada principalmente em novos recrutas do sul do país e de bairros urbanos pobres, lideraram a insurgência de baixa intensidade ocorrida nos anos 1990.

Há cinco anos os dois grupos de salafitas presos fizeram um acordo com o regime, segundo o qual seriam soltos se escrevessem depoimentos explicando em detalhes por que haviam interpretado as escrituras erroneamente ao tomar o caminho da violência e por que acreditavam que precisavam abandoná-lo. O resultado foram quatro volumes massudos de retificação teológica, expondo como e por que eles haviam se extraviado, e em 2006 eles foram libertados. Agora querem formar um partido próprio, argumentando que a Irmandade Muçulmana seria demasiadamente frouxa em suas convicções religiosas e demasiadamente propensa a meios-termos em sua atuação política; segundo eles, faz-se necessário um partido com maior integridade, que manifeste suas posições com clareza e se mantenha fiel a elas.

Ambas as tradições desse bloco salafita, o Gama’a al-Islamiyya e a Jihad, afirmam que agora rejeitam a violência e buscam somente persuadir outros a seguir as escrituras islâmicas de maneira mais estrita, mas há sérios atritos entre elas, e as tentativas de reuni-las têm sido infrutíferas até o momento. Originalmente, elas sustentavam que a democracia viola o Islã e queriam abolir a Constituição, o parlamento e as eleições, visando unir todos os muçulmanos para recriar o califado. Agora, o efetivo líder delas, Abboud Al-Zumar — no passado um coronel da inteligência militar e o cérebro por trás do assassinato de Sadat, encarcerado por trinta anos - tem aparecido nos noticiários por declarar que elas vão aceitar a democracia e respeitar os compromissos internacionais do Egito. Nem todos ficaram convencidos dessa conversão, mas um partido salafita provavelmente obteria uma votação muito pequena de qualquer jeito.

Por fim, há um fundamentalismo basicamente apolítico. Trata-se de puritanos que se aferram à letra das escrituras, com um mínimo de interpretação, e se dedicam a uma rigorosa observância das regras. Não diferentemente dos judeus ortodoxos, eles se importam com o que comem, com o que bebem, com o que vestem, com a maneira como se portam. Caracteristicamente, advogam o respeito por aqueles que estão no poder e se empenham de modo pacífico pela regeneração moral da sociedade. São bastante introvertidos e geralmente muito passivos no que diz respeito à política. Por certo, eles advertem contra os perigos do xiismo e se queixam de que não se tem feito o bastante para cercear as correntes sufistas, que contrariam suas crenças religiosas. No mais das vezes, porém, só se manifestam 
contra aquilo que considerem transgressões da moralidade, mobilizando-se pelo banimento de um livro, uma música ou um filme que julguem ser imoral. Eles não são madeira boa para a construção de um movimento político.

Pode-se dizer então que do ponto vista secular ou copta há pouco a temer quanto à configuração das forças islâmicas no Egito?

No dia seguinte ao plebiscito, o reitor da Universidade de Al-Azhar, Ahmed Al-Tayeb, enviou uma proposta ao governo com o intuito de requerer a autonomia da instituição em relação ao Estado, perdida em 1961, mediante a restituição de seu controle sobre terras e mesquitas waq $^{10}$, a reintegração de especialistas em lei islâmica à universidade e a mudança da forma de escolha do reitor, que não mais seria nomeado pelo governo, mas selecionado por clérigos seniores. Essas medidas teriam o efeito de garantir a independência da Al-Azhar e recapacitá-la como autoridade central em assuntos religiosos. Visto que a tradição dela é moderada, isso tenderia a reduzir interpretações radicais das escrituras e a tranquilizar aqueles que temem que concessões ao islamismo os tornariam potenciais reféns do textualismo estrito.

\section{O reitor que fez essas propostas foi nomeado por Mubarak?}

Exato. Mas ele é um ilustre acadêmico islâmico, com doutorado na Sorbonne, e se desligou do partido do governo quando foi nomeado, de modo que conta com amplo apoio. Pela proposta dele, o próximo reitor será escolhido, tal como era no passado, por um comitê de eruditos de todo o mundo islâmico, não só do Egito. No início do século $\mathrm{XX}$, a universidade teve um reitor tunisiano.

Em meio ao dramático processo sociopolítico em curso no Egito, quanta atenção a mídia e a opinião pública têm dado aos acontecimentos nas outras nações do mundo árabe?

Um alto grau de atenção. O efeito das sublevações no entorno sobre os egípcios tem sido duplo. Por um lado, à medida que eles observam o desencadeamento da violência militar no Iêmen, no Bahrein, na Líbia, na Síria, na Jordânia, eles cada vez mais têm razões para ser gratos ao Exército egípcio ao ver a tragédia causada pelo uso de tanques e projéteis contra os manifestantes. Por outro lado, eles vêm a perceber que aquilo por que estão passando faz parte de um processo histórico mais amplo que está convulsionando a região. Isso lhes dá certa sensação de segurança. Se o Egito estivesse isolado em sua revolta, as perspectivas de um retorno dos elementos do velho sistema e de seus aparatos de repressão seriam maiores. Mas os retrógrados agora estão fadados a olhar a seu redor e constatar a improbabilidade de que aquilo pudesse voltar a funcionar, já que
[10] No âmbito da lei islâmica, waqf é a doação de terras ou imóveis para usufrutos religiosos, de caridade ou de utilidade pública em caráter inalienável e perpétuo. [N.T.] 
uma imensa onda histórica engolfa o mundo que eles dominavam antes. Assim, os egípcios se sentem mais seguros, na convicção de que suas conquistas não serão perdidas e de que o tempo não irá voltar aos dias anteriores a 25 de janeiro.

\section{É possível fazer alguma previsão quanto às consequências da derrubada} de Mubarak?

As duas mudanças cujo advento se pode esperar decorrem daquilo que já aconteceu. As rédeas soltas da brutalidade policial contra os cidadãos e da exploração econômica dos indefesos serão refreadas, já que agora a população pode se posicionar, lutar, realizar manifestações e greves pelos seus direitos. Até que ponto vamos ter uma democracia de verdade? Estou bastante convencido de que o país ficará mais democrático, mas é improvável que se torne plenamente democrático. Há dois cenários possíveis. Poderá haver um governo disposto a anistiar muitos membros do partido do ex-governo e oficiais da polícia, permitindo que eles se reposicionem sob alguma outra roupagem, com um consenso geral de que as figuras proeminentes do regime serão responsabilizadas por seus delitos, mas as demais poderão voltar à ativa. A maior parte da população retornará à passividade, as redes clientelísticas persistirão e a polícia continuará a ser presunçosa e a receber altos salários. Por outro lado, se o fervor radical se intensificar e o governo ordenar a seus ministros que destituam os asseclas da velha ordem, estes vão se sentir acuados e não irão cair sem lutar, pavimentando o caminho ou para um retrocesso autoritário ou para uma ordem política mais reformulada.

Assim, o desfecho vai efetivamente depender da intensidade da maré revolucionária no Egito. Se o movimento permanecer como está agora, moderado e pragmático, teremos um Egito bem melhor do que aquele de antes, não uma democracia plena. Se o movimento ganhar força e ímpeto, não há como dizer o que pode acontecer. Afinal, no presente contexto não há nenhum movimento revolucionário com capacidade para assumir o controle de todas as instituições que precisam ser saneadas. Nasser tinha o Exército: ele podia mobilizar soldados para executar sua reforma agrária, para gerir fábricas, para subsecretariar a burocracia governamental. Na Rússia e na China havia quadros políticos para cumprir essas tarefas. Na medida em que não haja nenhum movimento revolucionário para preencher as lacunas, acuar oponentes sem contar com uma organização para neutralizá-los congela a revolta numa posição em que tão somente se fazem exigências e depois se espera pelo melhor possível.

HAZEM KANDIL, sociólogo egípcio, é doutorando no Departamento de Sociologia da Universidade da Califórnia em Los Angeles (EUA). 